\title{
画地単位の転換確率に基づく土地利用モデル LAND USE CONVERSION MODEL BASED ON TRANSITION PROBABILITY OF LOTS
}

\author{
大佛俊 泰*, 西松照生**, 吉川 徹*** \\ Toshihiro OSARAGI, Teruo NISHIMATSU and Tohru YOSHIKAWA
}

\begin{abstract}
Many studies on land use conversion have been carried out to provide fundamental information for the general plan of the future. Land use transition probabilities were usually estimated by calculating the areas of land in which land use categories were changed. However, it should be noted that the spatial unit of land use transition is a lot. This study describes a land use conversion model based on transition probability of lots. Change of land categories, division of lots, demolishing of buildings and reconstruction of buildings are described in this model. As an application of the model, we discuss the effect of land use policy by simulating the land use transition in the future.
\end{abstract}

Keywords: land use, lot, division of lot, land category, demolishing of building, reconstruction of building 土地利用, 画地, 画地分割, 地目, 家屋除却, 家屋更新

\section{1.はじめに}

都市・地域計画の分野においては, 将来の土地利用変化，およ び，その空間分布を予め把握しておくことは重要である。例えば， 都市マスタープランを策定する際には, 土地利用規制や都市基盤整 備などが将来の土地利用に及ほす影響について検討しておくことが 必要となる。そのため, 将来の土地利用変化予測に関する研究はこ れまで数多くなされてきた。例えば，そのなかでも代表的なものと して, 土地利用を含めた地域特性の相互関係をモデル化した計量経 済モデルやローリーモデルなどについては古くから研究されており， 今までに多くの優れた成果が報告されている奴～文2)。この種のモデ ルは,広域的な空間範囲に関わる諸変数を導入することが比較的容 易であることから，政策変数をはじめ様々な要因が対象地域全体に どのような影響を及ほすのかを評価する際に用いられてきた。しか し，モデルで扱われる諸变数が，ある空間的な広がりを持つゾーン 内の集計量として定義されるため，道路拡幅が沿道土地利用に与え る影響など詳細な空間特性を組み込むことは難しい。また，画地規 模分布や建築物の経過年数分布などの地域特性は, 集計量としても デルに組み込むことは可能であっても，それらの地域特性が将来の 土地利用変化にもたらす影響の詳細な過程を明らかにすることは困
難であった。

交通計画の分野では,ゾーンごとに個人の交通行動を集計してか らモデル化する方法と，交通行動の基本単位である個人（または世 帯）がどのような交通行動をとるのかをまずモデル化し，得られた 個人の交通行動をゾーン内で集計して交通需要を予測しょうとする 方法がある。前者は集計分析, 後者は非集計分析と呼ばれている。 今日，このような非集計的な分析が交通計画をはじめマーケティン グなど様々な研究分野において主流となりつつある背景には，従来 の集計分析に潜在する多くの課題だけでなく，「意思決定は，なぜ， どのように行われるのか」といった行動科学的なモデル開発への強 い要請がある文3)。

土地利用変化の将来予測モデルに求められる出力結果は, 関心の ある地域 (ゾーン) 内での土地利用変化面積 (集計量)である場合 が多い。実際，今までに提案されてきた土地利用変化の将来予測モ デルは, 町丁目単位など空間的には詳細なものも含めて, 基本的に はゾーン内での土地利用面積をもとにした集計型のモデルであると 言える。これに対して，非集計的な視点からの土地利用変化の分 析, すなわち, 土地利用の状態を決定付けている個々の活動主体 （世帯や事業主）に着目した分析，換言すれば，土地利用変化の基
* 東京工業大学大学院情報理工学研究科 助教授. 博士 (工学)

** 東京工業大学大学院情報理工学研究科 大学院生 (研究当時)

*** 東京都立大学工学研究科建築学尃攻 助教授・博士 (工学)
Assoc. Prof., Graduate School of Information Science and Engineering, Tokyo Institute of Technology, Dr. Eng.

Graduate Student, Graduate School of Information Science and Engineering, Tokyo Institute of Technology

Assoc. Prof., Department of Architecture, Graduate School of Engineering, Tokyo Metropolitan University, Dr. Eng. 


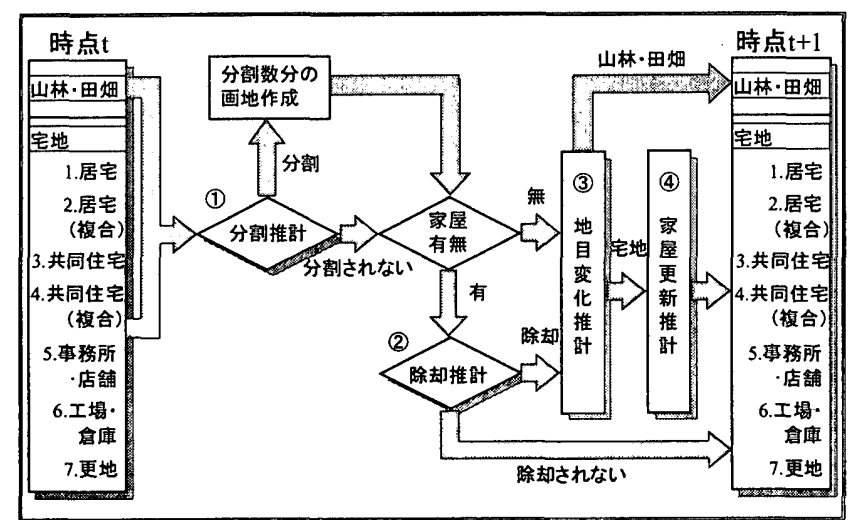

图1土地利用転換モデルの概念図

本単位である画地の状態変化に着目した土地利用分析は, 上記の交 通需要モデルの発展例と同様に，極めて自然な行動科学的な視点か らの展開であるといえる。このような非集計分析は, 前記の詳細な 空間特性の組み込みを可能にする。また，地域特性の影響の詳細な 過程を明らかにすることによって, 集計分析による予測の精度向上 や誤差評価に役立つ知見を与えることが期待される。

他方で，近年の地理情報システムの進展を背固として，土地利用 に関するデータベースが急速に整備されるようになった。容易に入 手可能となった複数時点のデータを用いて, 土地利用変化をマルコ フ連鎖としてとらえた研究も多く試みられている文4) 一文6)。筆者らも これまで幾つかの分析方法の提案と，現実のデー夕を用いた実証分 析を試みてきた文7)一文11)。この方法は,地域特性の相互関係のモデ ル化は困難ではあるが，マルコフ連鎖の遷移確率を画地の転換確率 と考えることによって，画地の状態変化にも適用できる可能性を持 っている。しかし, 従来のマルコフ連鎖型土地利用モデルを行動科 学的な視点から眺めると, 議論すべき課題が多く残されているよう に思われる。その中でも次の点に関する茷論は重要である。すなわ ち，従来までのマルコフ連鎖型土地利用転換モデルでは，モデルの 心臓部ともいえる遷移確率行列が，ある 2 時点間で観測された土 地利用変化面積をもとに推定されている。この方法は非常に簡便で あるものの，実際の土地利用転換の構造を見誤ってしまう危険性が ある文10)。具体的には，面積から推定した場合（面積ベース）と， 画地の数をもとに推定した場合（画地べース）とでは, 遷移確率行 列が大きく異なる文11)。面積べースの推定では, 個々の立地主体の 面積が不明であるので, 非常に稀に生じる大規模開発による変化 と，頻繁に発生している小規模変化とが基本的には区別されず，そ のため，「個々の画地における土地利用変化の起こりやすさ」，す なわち，個々の立地主体に着目した遷移確率を正確に推定すること ができない。非集計分析的な視点からすれば，画地ベースの推定方 法をとるべきであるが，使用可能なデータの制約から，従来までは メッシュデータをもとに面積ベースで推定されてきた。

このような課題に対して, 筆者のひとりは, 画地ベースの遷移確 率を,メッシュデータから推定するための方法を提案している文11)。 しかし，メッシュデータを用いている点にかわりは無く，擬似的な 画地ベースの遷移確率にとどまっている。

そこで本研究では，従来のマルコフ連鎖型土地利用モデルにかえ て, 画地単位の転換確率に基づく一連の確率過程としての土地利用

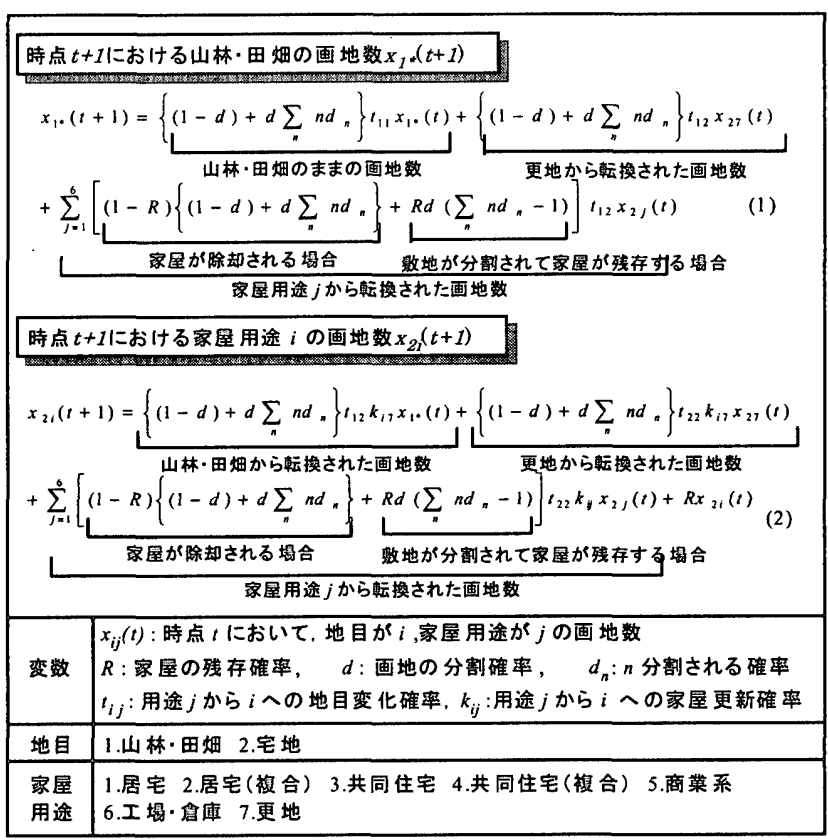

图 2 土地利用転換モデルの定式化

モデルを構築する。このためにまず，地方自治体等で整備されてい る固定資産課税台帳などの非空間データと画地の位置や形状などに 関する空間デー夕とを一体的に扱い，画地単位の原デー夕を構築す る方法を提案する。次に, 各画地に拈ける「地目の変化」，「画地 の分割」，「家屋の除却」，「家屋の更新」という事象を記述する部 分モデルを構築し，これらを統合した土地利用モデルを提案する。 さらに, 推定されたパラメータをもとに土地利用モデルの推計精度 について検討するとともに，将来の土地利用についての様々なシミ ユレーションを行い, 用途地域変更や道路幅員拡幅などが土地利用 変化へ及ぼす影響について検討する。

\section{2。土地利用転換 テデルと統合データベースの棈築}

\section{（1）土地利用転換の考え方とモデル化}

実際の都市空間内においては,メッシュデータのように等間隔で 区切られた地点がそれぞれ独立に変化しているのではなく，様々に 形状の異なる画地が一つの単位となって変化している。また，特に 既成市街地に扔いては，既存家屋が除却され，新たな用途の家屋が 建設されることによって，土地利用変化が生じている。すなわち， 家屋の除却のされやすさが，土地利用变化の方向やスピードを左右 していると考えられる。さらに，山林・田畑などでは，土地の一部 を分割して宅地化し，分譲住宅として売り出すことなども散見さ れ，地目の変化だけでなく画地の分割についても議論しておく必要 がある。以上のように，「地目の変化」が主たる関心事となる郊外 部での土地利用変化とは異なり，既に宅地化が進行した既成市街地 などにおいては，より具体的な土地利用のされ方や土地性状の変 化，すなわち，「画地の分割」「家屋の除却」「家屋(用途)の更新」 を含めた，より詳細な土地利用モデルが必要である。そこで，本研 究では, 従来から「地目の変化」で表現されてきた「土地利用変化」 という概念を拡張し，土地と家屋の組み合わせを用いて，「画地の 分割」,「家屋の除却」,「地目の変更」,「家屋の更新」という視 


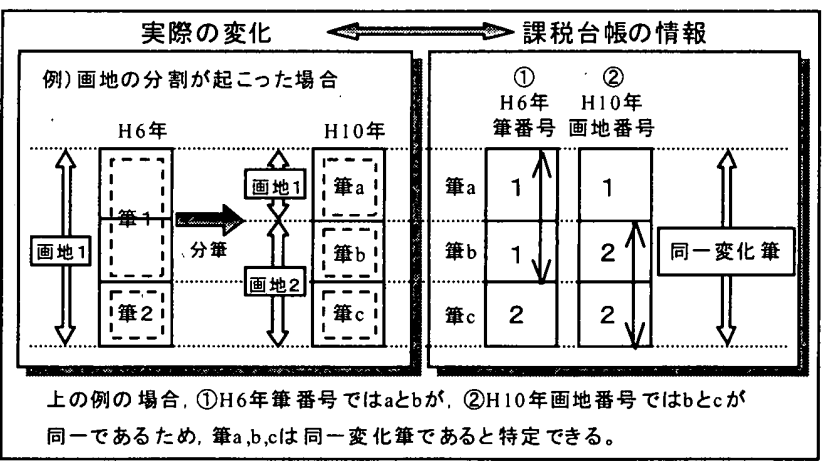

図 3 同一变化䈉の同定方法

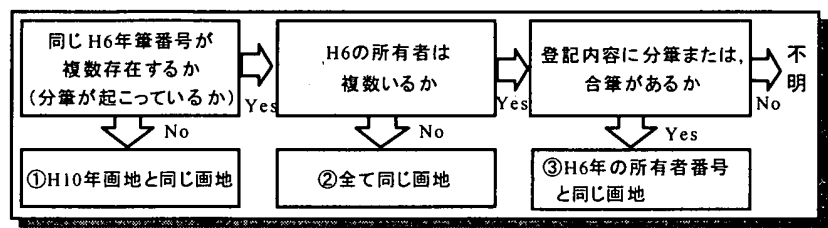

图 4 同一画地の同定方法

点から土地利用変化をとらえることにする。

モデルの構成を，図1に示してある。まず，(1)各々の画地が分 割されるか否かが推定される。分割されると推定された画地では， さらに，何個の画地に分割されるかが推定される。次に，(2)既存家 屋がある場合には家屋が除却されるか否かが推定される。除却され ないと推定されれば，用途变化は起こらないものと考えて，次の時 点の状態が定まる。続いて, (3)この段階で家屋が建っていない画地 については，地目に変化が生じるか否かが推定される。地目が山 林・田畑と推定されれば，次の時点の状態が定まり推定は終わる。 最後に，(4)この段階で画地の地目が宅地であれば，家屋更新につい ての推定がなされる。以上のモデルを定式化し，図2に示した。

\section{（2）画地データの構築}

本研究では,ケースス夕ディとして東京都三鹰市における平成 6 年から平成 10 年の固定資産課税台帳デー夕をもとに転換確率を推 計する。そこで，まず画地単位の原デー夕（以下，画地デー夕）を 構筑する必要があるため，その方法について述べる。

\section{(1)同一画地の同定}

固定資産課税台帳には, 土地（筡）の情報が非空間データとして 記録されている。このとき，すべての情報が各時点において空間情 報とリンクされていれば, 筆から画地を構成することは比較的容易 である。しかし, 現状では過年度の空間情報が存在しないため, 手 元にある情報から, 過去の同一画地の状態を推定する必要がある。 ただし，分筆や合筆が起こっていると，一つの画地には複数の筆が 関与することになる（図 3)。そこで, まず任意の画地の変化過程 に関与した筆（同一変化筆）の特定を行った。図３に示すように， 平成 6 年の筆番号と平成 10 年の画地番号が分れば, 同一变化筆を 特定することが可能となる。

次に，図 4 に示すように，同一変化筆の中で分筆が起こってい るかどうかを判定し, 起こっていない場合は平成 6 年も平成 10 年 と同じ画地であったと判定する。分割が起こっている場合，平成 6 年の識別コードを参照し, 同一の所有者であれば，もともと同一変 化筆にある筆は，すべて一つの画地であったと判断する。一方，所

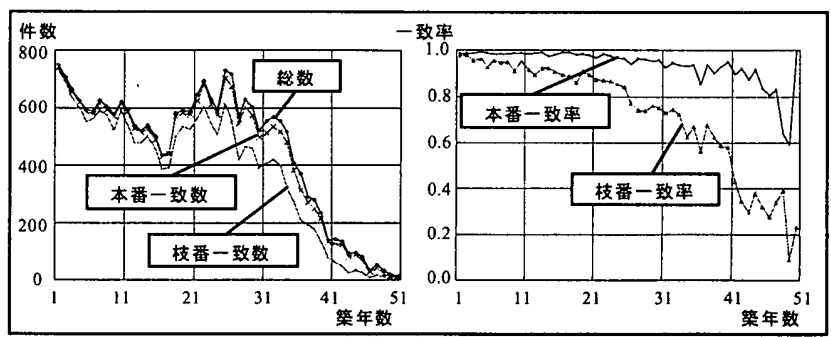

図 5 筑年数別の家屋数と地番一致率

表 1 画地に関する情報

\begin{tabular}{|c|c|c|c|c|c|c|c|c|}
\hline \multirow{2}{*}{\multicolumn{2}{|c|}{\begin{tabular}{|l} 
哾明柿数 \\
\end{tabular}}} & \multicolumn{7}{|c|}{ カテゴリー } \\
\hline & & 1 & 2 & 3 & 4 & 5 & 6 & 7 \\
\hline \multirow{2}{*}{\begin{tabular}{|l} 
画 \\
地 \\
形 \\
品
\end{tabular}} & H10画地面皘 & $\sim 100 \mathrm{~m}^{2}$ & $\sim 500 \mathrm{~m}^{2}$ & $\sim 1000 \mathrm{~m}^{2}$ & $1000 \mathrm{~m}^{2} \sim$ & & & \\
\hline & 前面道路幅員 & $\sim 4 \mathrm{~m}$ & $\sim 6 \mathrm{~m}$ & $\sim 10 \mathrm{~m}$ & $10 \mathrm{~m} \sim$ & & & \\
\hline \multirow{3}{*}{ 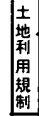 } & 用途地城指定 & 1.2经殿 & 1.2中高局 & 1. 2住居 & 晸住居 & 近瞵商重 & 畐果 & 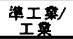 \\
\hline & 容積争(X) & 50 & 80 & 100 & 150 & 200 & 300 & $500 / 600$ \\
\hline & 建ぺい尔( & 30 & 40 & 50 & 60 & 80 & & \\
\hline \multirow{3}{*}{ 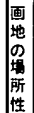 } & 地区 & 商果地区 & 工堨地区 & 型用住宅 & 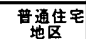 & & & \\
\hline & ハスス停までの唊碓 & $\sim 100 \mathrm{~m}$ & $\sim 200 \mathrm{~m}$ & $\sim 300 \mathrm{~m}$ & $300 \mathrm{~m} \sim$ & & & \\
\hline & 熰までの距離 & $\sim 500 \mathrm{~m}$ & $\sim 1000 \mathrm{~m}$ & $\sim 1500 \mathrm{~m}$ & $1500 \mathrm{~mm}$ & & & \\
\hline
\end{tabular}

有者が複数いる場合には，所有者ごとに各々画地を構成し，平成 6 年に扔ける画地とする。この際，筆の面積が $30 \mathrm{~m}^{2}$ 未満の変化につ いては，画地の分割ではなく，隣接する敷地同士を調整するための 行為であるとみなし，分割とは考えないことにした。また，画地の 統合については，統合前の筆に関する情報が存在せず，統合が起こ る件数も少ないことから，本研究では考虑しないこととした。

\section{(2)家屋位貫の同定}

家屋に関する非空間情報についても空間情報とリンクされてい ないため, 家屋データに記載されている土地の地番をもとに家屋の 位置を同定する。しかし，家屋デー夕に記載されている地番は，建 設された時点の地番であるため，現時点の地番とは整合しない可能 性がある。そこで，地番の一致率について検証するため，空間情報 とリンクされている平成 10 年に現存する家屋デー夕を用いて, 実 際の地図上の地番と台帳上に記载されている地番の一致率を求めた (図 5 )。本番までの一致については，築 40 年ほどの建物でも $80 \%$ 近く一致しているが，詳細な位置情報を与える枝番においては，古 い家屋ほど一致率が低い。これは，建設されてから現在までの間 に, 分筆や合筆が発生し, 古い家屋ほど地番が変更される可能性が 高くなるためと考えられる。

\section{3.土地利用転換確率の推定}

以下で推定する各転換確率は，画地の形状，場所性，土地利用規 制等の諸条件（表 1）によって大きく異なると考えられる。そこ で, 土地利用転換の構造を説明するためにどの変数を組み込むこと が適切であるのかについて検討する。一般に，説明変数が多いほ ど，転換構造を詳しく知ることができるが，デー夕数が限られてお り，分類が細かいと推定値が不安定になる。そこで, AIC（赤池情 報量基準）文12）に基づく分割表解析モデル注1）を用いて，統計的に 有意な要因から順にモデルに組み込んでいく方法で転換確率を推定 する。ただし，統計的に有意となる変数の組み合わせが，実際の都 市政策について検討する上で活用できなければ意味がないため，こ 


\begin{tabular}{|c|c|c|c|c|c|}
\hline \multicolumn{3}{|c|}{ I，1変数の堨合，「現存家屋」を操用 } & \multicolumn{3}{|c|}{ II.2変数の埸合，「画地面䅡」を探用 } \\
\hline 磁明変票 & 分類数 & AIC & 裞明変数 & 分䫋数 & AIC \\
\hline 1現存家屋の有無 & 2 & -777.81 & 1目地面 & & -1057.28 \\
\hline 2 画地面标 & & -434.40 & 2 前面道路制自 & $\frac{3}{3}$ & -810.83 \\
\hline 3 地目 & 2 & .47 .03 & 3 地目 & 2 & -791.23 \\
\hline 4 的面道路蝠自 & 3 & -3.20 & 4 4 & 2 & -787.10 \\
\hline & & -1.96 & 5 地区 & & -785.16 \\
\hline 6 用逄指定 & 5 & .0 .19 & 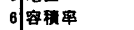 & & -778.84 \\
\hline 7 地区 & 4 & 0.01 & 订用途指定 & 5 & -778.21 \\
\hline 8 容程果 & 5 & 0.28 & 8 建へい品 & 4 & -777.51 \\
\hline 9 䒔ス电 & 2 & 0.49 & 9 吸 & 2 & .775 .08 \\
\hline 10建べい中 & 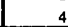 & 1.89 & & & \\
\hline
\end{tabular}

3変数以上も同様に, AIC值が增加しない匴囲において，操用する夜数を暊次增やしな がら、最良のモテルを探䇣する。

\begin{tabular}{|c|c|c|c|c|c|}
\hline 变数の伊䋖 & 第 1 叒数 & 第2 翇数 & 第3 夜数 & 第4 变数 & 第5 変数 \\
\hline 镜明变 & 现青家e & 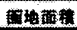 & 塔目 & 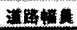 & 八反保 \\
\hline NC値 & -777.81 & -105728 & -1121.46 & -117250 & $-1140,32$ \\
\hline
\end{tabular}

上例の哠合，5変数目の「バス停」で增加しているため、4夜数が最良モテルとなる。

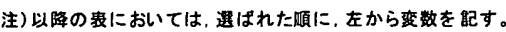

さらに以下の条吽を责虔して、シミュレーションに用いる変数の組み合わせを選択する。

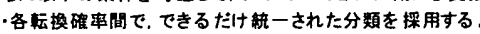

・AIC值が大きく增加しなければ、できるたシけ多くのカテゴリーをもつ变数を操用する。

・AIC值が大きく增加しなければ、できる扑多くの变数を探用する。

・政策变数とみなしやすい变数を告して探用する。

图 6 モデルの道出方法（目的変数が画地分割の例）

表 2 画地の分割モデルの分析結果

\begin{tabular}{|c|c|c|c|c|c|c|c|}
\hline & 第1変数 & 第2 変数 & 第3変数 & 第4变数 & 第5変数 & AIC值 & 分類數 \\
\hline \multirow{2}{*}{$\begin{array}{c}\text { 画地の } \\
\text { 分割 }\end{array}$} & \multirow{2}{*}{ 現存家屋 } & \multirow{2}{*}{ 画地面皘 } & \multirow{2}{*}{ 地目 } & \multirow{2}{*}{ 道路幅員 } & & -1172.50 & 32 分類 \\
\hline & & & & & バス停 & -1145.59 & 48分類 \\
\hline
\end{tabular}

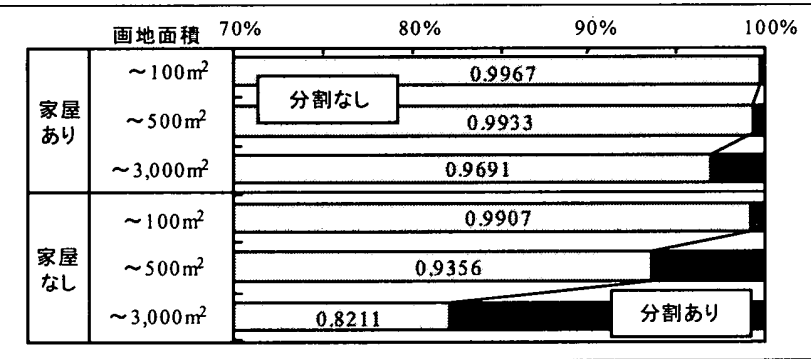

图 7 画地の分割確事の例（地目が宅地の場合）

れとは別にシミュレーションを行う際に用いる变数の組み合わせに ついても検討した。変数の採択方法については, 図 6 に示すとお りである。

\section{(1) 画地の分割確率}

既に家屋が建っていても，画地の一部を切り売りすることもあ る。このような事象についても考慮するため，ここでは「現存家屋 の有無」も説明変数の中に加えることにした。表 2 , および, 図 7 に示すように, 現存家屋の有無の説明力が最も高く, 家屋がない場 合ほど分割確率が高くなる。さらに残りの変数の中から 2 番目の変 数について検討すると，「画地面積」が選ばれた。推定値をみると， 面積の広い画地ほど, 分割確率は高く推定されている。以下, 同様 に, 説明変数を增やしていくと, 表 2 に示す変数が有意な説明変数 として採用された。また，後で行うシミュレーションのために，バ ス停までの距離も変数に含めて分割確率を推定してある。

\section{（2）家屋の除却確宣}

家屋の除却確率は，他の転換確率とは異なり，「ある時点におい て, 家屋は除却されるまで存続し続けた」という事実を考慮して推 定しなければならない。このことについては, 建築物の除却確率に
表 3 家屋の除却モデルの分析結果

\begin{tabular}{|c||c|c|c|}
\hline \multicolumn{2}{|c|}{ 家屋の除却 } & \multicolumn{3}{|c|}{ 3变数 } & 1200 分類 \\
\hline 锐明变数 & 家屋用途 & 用途地域指定 & 籍年数 \\
\hline 分類数 & 3 & 5 & 笑80年まで \\
\hline
\end{tabular}

表 4 地目の变化モデルの分析結果

\begin{tabular}{|c|c|c|c|c|c|}
\hline 5 & 第 1 変数 & 第2変数 & 第 3 変数 & AIC值 & 分類数 \\
\hline \multirow{2}{*}{$\begin{array}{l}\text { 地目の } \\
\text { 変化 }\end{array}$} & \multirow{2}{*}{ 分割の有 無 } & \multirow{2}{*}{ 画地面皘 } & 前面道路幅員 & -1189.05 & 12 分類 \\
\hline & & & 用途地城指定 & -1183.14 & 30分類 \\
\hline
\end{tabular}

表 5 家屋の更新モデルの分析結果

\begin{tabular}{|c|c|c|c|c|c|c|}
\hline 3 & 第1变数 & 第2狓数 & 第3変數 & 第4変数 & AIC值 & 分数数 \\
\hline \multirow{2}{*}{ 居电 } & \multirow{2}{*}{ 画地面糟 } & 分剽の有無 & & & -109.55 & 6分類 \\
\hline & & 用途地域指定 & & & -81.31 & 15 分類 \\
\hline $\begin{array}{c}\text { 居宅(袒合 } \\
※\end{array}$ & 分割の有無 & & & & -20.07 & 2分類 \\
\hline 共同住宅 & 分割の有無 & 画地面精 & & & -89.00 & 6分類 \\
\hline $\begin{array}{r}\text { 共同住宅 } \\
\text { (模合) }\end{array}$ & 分剖の有無 & & & & -1.27 & 2分類 \\
\hline 蓜乘系 & 分㓻の有無 & & & & -6.48 & 2分類 \\
\hline 工埸合庫 & 分割の有無 & & & & -22.48 & 2分類 \\
\hline \multirow{2}{*}{ 更地 } & \multirow[b]{2}{*}{ 分割の有無 } & \multirow[b]{2}{*}{ 面地面栍 } & 建へい事 & & -2152.88 & 24分類 \\
\hline & & & 用途地域指定 & 道路幆員 & -2032.52 & 60分類 \\
\hline $\begin{array}{l}\text { (※) 居 } \\
\text { 場合. } \\
\text { (椱合) }\end{array}$ & $\begin{array}{l}\text { 井同住宅 } \\
\text { の居宅や } \\
\text { て分類 L }\end{array}$ & & $\begin{array}{l}\tau, 30 \mathrm{~m}^{2} \text { 以上 } \\
\text { するため, 家 }\end{array}$ & 商䒚系 & $\begin{array}{l}\text { が含まれて } \\
\text { 复合)，共后 }\end{array}$ & $\begin{array}{l}\text { いる } \\
\text { 司住宅 }\end{array}$ \\
\hline
\end{tabular}

ついて検討した研究文13)，文14）の結果を参考に, 表 3 に示す説明変 数を採用した。

\section{（3）地目の变化確率}

宅地から山林・田畑への転換は極めてまれであるため，条件によ らず確率は一定と考えた。一方，山林・田畑であった画地の変化確 率については，画地を分割して宅地化し，居宅を分譲するという一 連の現象についても考慮するため, 説明変数の中に「画地分割の有 無」も加えることとした。採択された变数の結果を表 4 に示して ある。表 4 より,「画地分割の有無」の説明力が最も高く, 分割が あった画地では，山林・田畑が宅地化される確率が非常に高いこと が確諗できる。

\section{(4)家屋の更新確率}

ここでは，ある用途の家屋がどのような用途に更新されるかとい った現象において，どのような要因が関与しているのかを求めた。 表 5 に採択された説明変数の結果を示す。居宅からの更新では, 「画地面積」と「画地分割の有無」が最良の評価を与える。しかし， 後で行うシミュレーションでは, 土地利用政策の影響について議論 したいので, 評価が大きく劣らない「用途地域指定」についても採 用し, 更新確率を推定した。共同住宅では,「画地分割の有無」と 「画地面積」の 2 変数が選ばれ, 画地面積が広いほど, 共同住宅へ更 新されやすく，また，画地の分割がある場合には，居宅へ更新され やすいことが判明した。居宅（複合），共同住宅（複合），商業系 施設, 工場・倉庫では，いずれもサンプル数が少ないことが起因し て，「画地分割の有無」のみが採用された。また，更地からの更新 では, 3 変数が採択されたが,他の転換確率で採用された变数との 関係から,シミュレーションでは表 5 下段に示す変数の組み合わ 


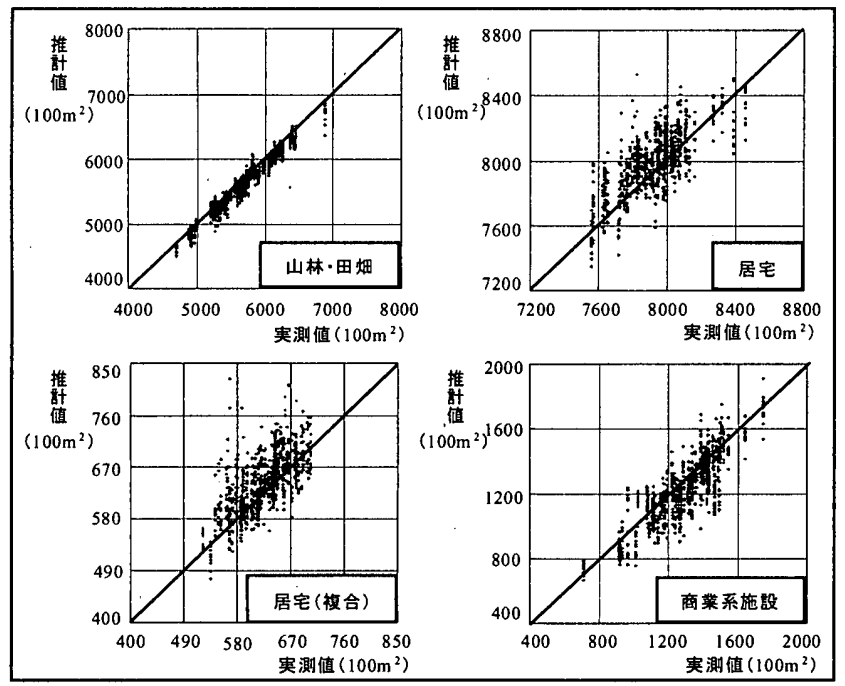

图 8 推計值と実剆值の比較（面䖽集計の場合）

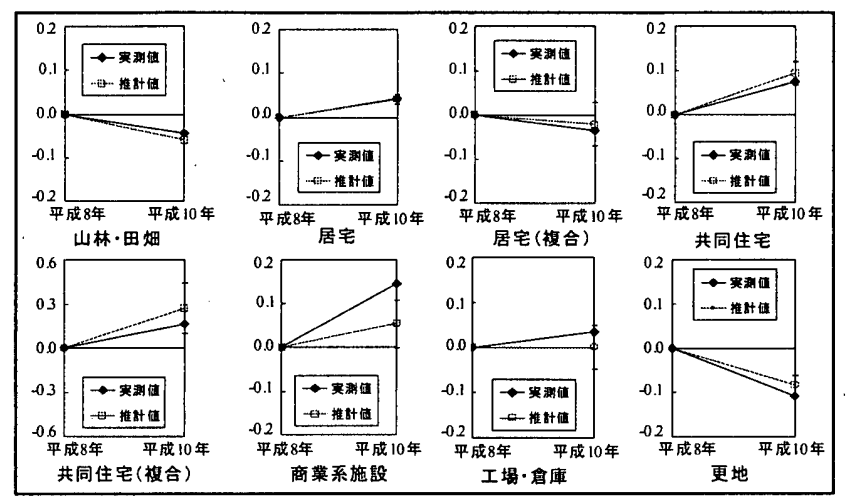

図 9 推計誤差と変化の方向（面秘集計の埸合）

せを採用することとした。前面道路幅員が広い場所や, また商業地 域などでは商業系への更新確率が高く推定されている。

\section{4. モデルの適合性検部}

\section{（1）モデルの適合性についての検討}

推定されたパラメータをもとに，モデルの適合性について検討す る。具体的には,すべての画地をランダムに $1 / 4$ と3/4の 2 組に 分け, $3 / 4$ の画地で転換確率を推定し, 残りの $1 / 4$ の画地で推計を 行い，適合性を検証した。既に述べたように推定自身は画地単位で 行っているが, 都市計画においては面積に関する情報が求められる ことが多い。そこで, 推定結果の適合性検証については，面積をも とに行った。図 8 には, 平成 10 年の推定值と実測值の関係の一部 を示してある。居宅（複合）において若干過大推定されているが， おおむね良好な適合性を示している。

\section{(2) 時間的安定性についての検討}

推定されたパラメータが将来予測においても有効であるかどう かについては，撖密には検証することはできない。そこで，平成 6 年から平成 8 年の 2 年間でパラメー夕を推定し, 平成 8 年から平成 10 年の変化を予測することで, 簡便な適合性検証を試みた。ここ では, 誤差の大きさについてだけでなく, 各用途の土地利用の変化 が増加か減少かという転換の方向についても検証した。図 9 は，

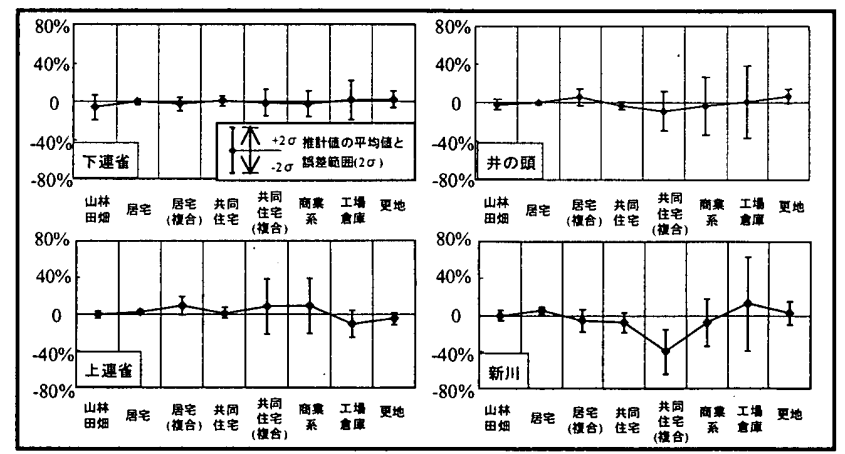

图 10 地区別の推計俱差と箅囲（面积集計の埸合）

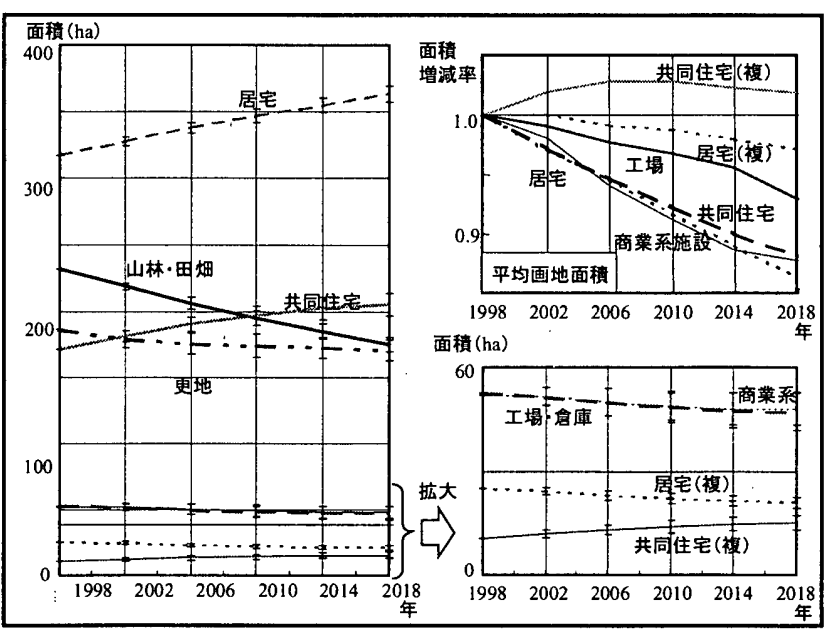

図 11 土地利用予測の結果（三鹰市全体）

実測值に対する推定残差の割合を示したものであり，おおむね良好 な適合性を示していることがわかる。

一般に，マルコフ連鎖型のモデルにおいては，遷移確率行例の定 常性が仮定される。しかし, 中長期的な社会経済活動と密接に関連 している土地利用変化を記述する際には，この仮定はあまりに強い 仮定であると言わざるを得ない。モデルの実際的な適用方法として は，データベースの更新などと合わせて，順次新たなデー夕を加え ながら推計值や推計精度の見直しを行うことが必要である。例え ば，遷移確率の時間的変化を組み込むために提案した方法文11)など を適用することも考えられる。

\section{（3）推定可能な空間籍囲についての検討}

推定されたパラメー夕を比較的狭い範囲へ適用することの是非 について検討した。三鹰市全体でパラメータを推定し，11町ごとに 推計を試み，適合性を検証した（図10）。全体としては，おおむね 良好な適合性を示しているが, 新川で, 多少推計結果にばらつきが 見られる。このように空間範囲が狭くなると, 大規模な画地につい ての推定が結果に大きく影響するので, 面積集計レベルでは誤差が 生じやすくなる。比較的狭い範囲へ適用する際には注意を要する。

\section{5. 将来土地利用予測のシミュレーション}

\section{(1) 将来土地利用予測からみた分析}

推定パラメータをもとに, 三鹰市全域における土地利用を 20 年 先まで推計した（図 11）。面積的には，山林・田畑が大きく減少す 


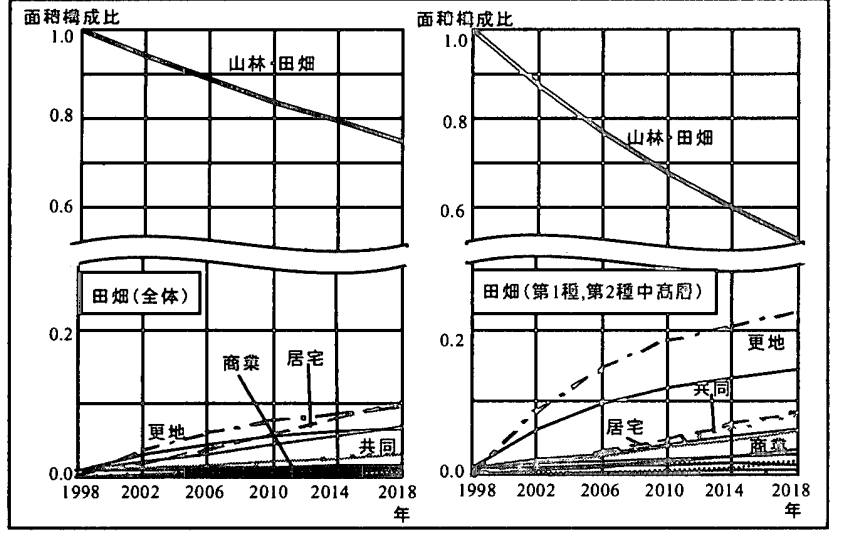

图 12 山林・田㚼の転換方向と䏅㡺

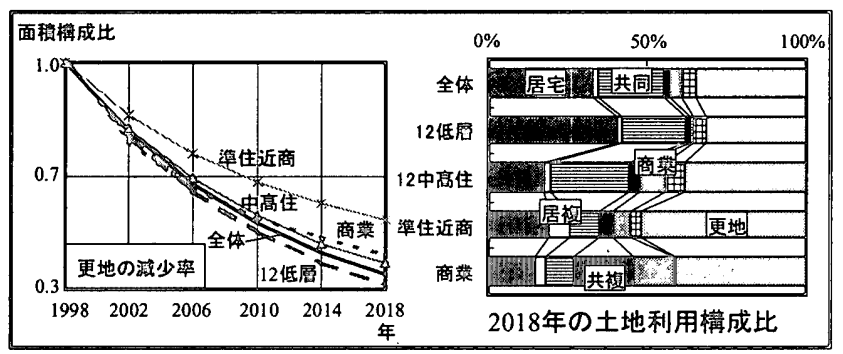

图13 更地の転換方向と遚搭

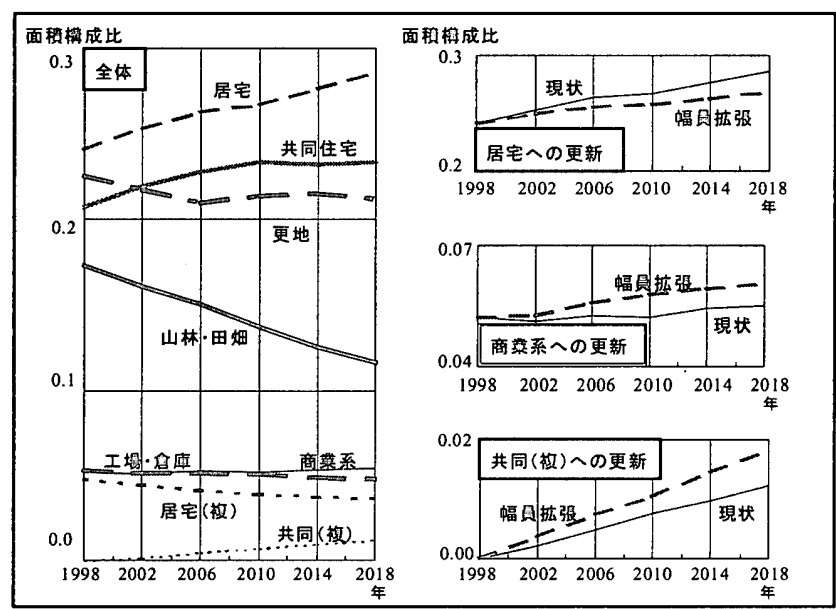

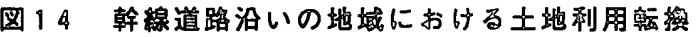

るのに対し，居宅，共同住宅は大きく増加し，宅地化が進展するこ とが読み取れる。また，商業系施設についてみると（図11右下）， 工場・倉庫と同様に微減していることがわかる。しかし，商業施設 と複合している共同住宅の割合は増加しており，今後，商業施設か ら共同住宅（複合）へ更新されていく可能性が伺える。さらに，画 地ごとの平均面積について検討した（図 11 右上）。居宅や共同住宅 などでは，全体の面積は増加しているが，一つ一つの画地面積にお いては商業系施設と同様に大きく減少しており，画地の狭小化が進 行することがわかる。また，共同住宅（複合）においては，平均画 地面積は微增して抢り，一般の共同住宅とは異なり，家屋更新の際 に画地は分割されにくく，むしろ，より大規模な画地が地目変化な どによって新たに生成され，比較的大規模な建物が建設される可能 性がある。

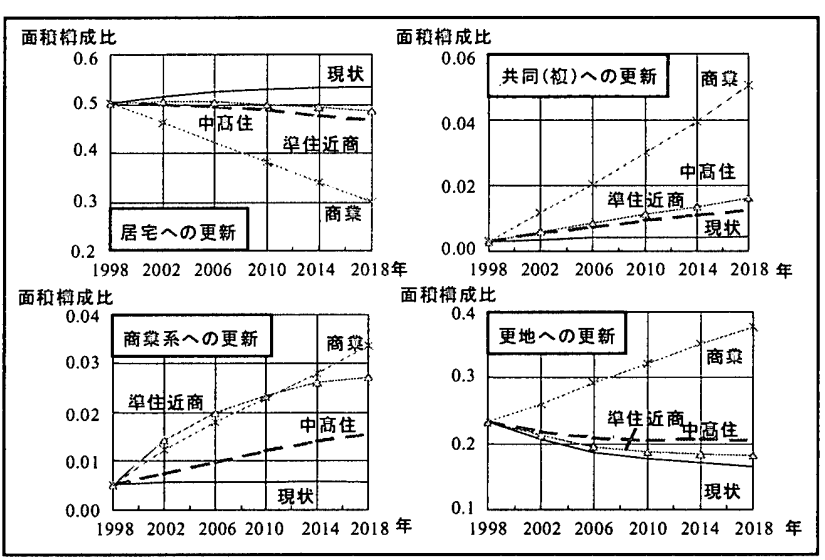

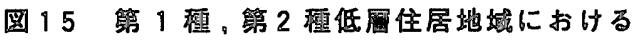

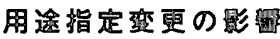

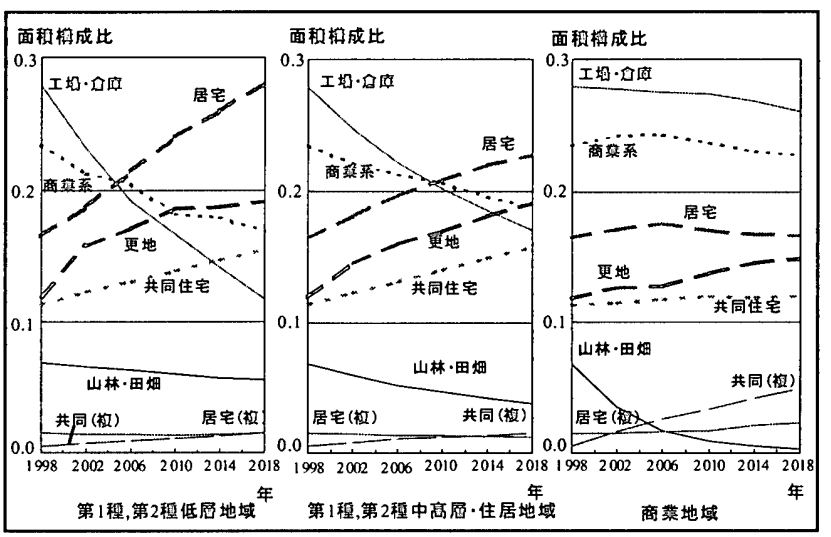

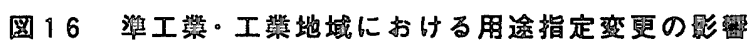

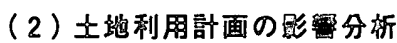

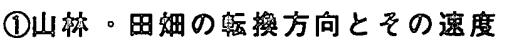

山林・田畑の転換について詳細に検討した(図 12)。現在の山林· 田畑は, 面積では 20 年間で約 $75 \%$ にまで減少することがわかる。 その転換先の用途は居宅か更地であり，居宅への転換は今後も大き く増加する傾向にあることがわかる。さらに用途地域の違いによる 転換先の違いについて検討した（図 12 右）。第 1 種, 第 2 種中高層 住居専用地域 - 第 1 種, 第 2 種住居地域では, 宅地化が非常に早く, 20 年間で約半分が宅地化されることがわかる。また，他の用途指 定に比べて, 共同住宅や商業系施設, 更地へ更新される割合が非常 に高い。それぞれ全体平均の約 3 倍, 5 倍，2 倍の面積が転換してお り，用途地域指定の違いによる影響が明瞭に現れている。

\section{(2)画垉の运換方向とその迹度}

山林・田畑と同様に更地の推移についても検討した(図 13)。現 存する更地は, 20 年後には面積で $35 \%$ にまで減少した。また, 用 途地域別の転換をみると（図 13 右）, 準住居地域・近隣商業地域 と商業地域では比較的転換は少なく, 前者では居宅（複合）への， 後者では共同住宅（複合）や商業系施設への転換が比較的高くなっ ている。

\section{(3)幹缐道路沿いの地域における土地利用捏換分析}

都市計画道路の幅員を拡張した場合における，将来の土地利用へ の影響について検討した（図 14）。現状に比べ, 居宅への転換が押 
さえられ，逆に商業系施設や共同住宅(複合) への転換が増加する 傾向が現れている。したがって, 道路拡幅計画の過程においては, 沿 道地域が無秩序に開発されないよう開発ポテンシャルをコントロー ルする必要がある。

\section{(4)用途地域指定別の土地利用転換分析}

駅前の近隣商業地域，商業地域と隣接する第 1 種，第 2 種低層住居 尃用地域に着目し, 用途地域指定の変更による影響について検討し た(図 15)。用途地域指定を変更しなければ, 居宅は増加の方向にあ るが，第 1 種，第 2 種中高層住居専用地域・第 1 種，第 2 種住居地域， 準住居地域・近隣商業地域, 商業地域のいずれの用途指定へ変更し ても居宅は滅少に転じることが分かる（左上）。一方, 用途指定の変 更により，共同住宅（複合）や商業系施設への転換は增加しており （右上,左下），特に，商業地域へ変更すると，大きく増加する可能性 が読み取れる。つまり，利便性の高い駅前などにある第 1 種，第 2 種 低層住居専用地域においては, 用途地域指定を緩めると商業系施設 などへの転換が急速に進行する可能性がある。

また，準工業地域・工業地域では，工場の移転・廃業にともなう 跡地利用の問題など, 用途地域指定の改正について十分に議諭して おく必要がある（図 16）。第 1 種, 第 2 種低層住居専用地域に变更す ると，居宅などの住居系が增え，住宅地として成育していくのに対 $し$, 第 1 種, 第 2 種中高層住居尃用地域. 第 1 種, 第 2 種住居地域に 指定すると居宅，共同住宅，商業系施設，工場・倉庫，更地といった 用途が構成比 $20 \%$ 付近で混在した土地利用構成になることが伺える。 また, 商業地域に指定した場合, 変化の速度は緩やかで, 山林・田畑 のみが急速に宅地化されていくことがわかる。以上のように，工業 系の地域では，次に指定される用途指定によって大きく転換の方向 が異なることから，転換方向については十分吟味した上で用途指定 は設定されるべきである。

\section{6.まとめ}

本研究では, 面積をもとに土地利用遷移確率を推定していた従来 の方法にかえて，画地単位で転換確率を推定する方法を構築し，これ をパラメータとして組み込んだ土地利用モデルを提案した。具体的 には，まず固定資産課税台帳などの非空間デー夕を，画地単位の空間 データとリンクして一体的に活用することの重要性と具体的な方法 を示した。さらに, 各画地においで,「地目の変化」,「画地の分割」, 「家屋の除却」，「家屋の更新」という事象を記述する部分モデルに ついて検討し，それらを統合化した土地利用モデルを提案した。モ デルの適合性, 時間的安定性, モデルの適用空間範囲に関する検証を 行い良好な結果を得た。さらに, 土地利用変化のシミュレーション
を行い，用途地域指定や道路幅員の変更が将来の土地利用に及ほ す影響について考察した。本モデルを用いれば，具体的な土地利 用政策と実際の土地利用変化の様子と対応させながら検討するこ とが可能となることを示した。

本稿は三鹰市との共同研究文15)において，筆者らが行った研究を もとに文献 16)を加筆・修正したものである。

注

1)分割表解析モデルの理論と応用については, 文献12)において詳紐に解説 されている。例えば画地分割確率を推定する場合にはまず,すべての画 地を面積情報などをもとに幾つかのクラスに分類して分割されるか否かの 観測度数を求め, 分割表(クロス表)を作成する。この観測度数を得る確 率が多項分布に従うことを利用して対数尤度関数を定義する。この関数を 用いて多項分布確率を最尤推定し，さらにAICの值を計算す机は，各クラ スで観測確密が異なるかどうか，すなわち，面積などの画地属性が画地分 割の発生と関連性があるのか,独立であるのかを判断することができる。

\section{参考文献}

1) 金子敬生ほか：地域経済の計量分析, 勁草曹房, 1973

2) David Foot(青山吉隆ほか訳):都市モデルー手法と応用, 丸善株式会杜, 1984.6

3 ) 土木学会土木計画学研究委員会: 非集計行動モデルの理論と実際, 丸善株 式会社, 1995.5

4 ）金俊栄ほか:土地利用遷移行列による都市の土地利用用途転換の分析, 日 本建築学会計画系論文報告集 , 424,69-78, 1991.6

5 ）石坂公一：土地利用溧移行列の分析手法に関する考察 その 1 , 日本建 築学会計画系論文報告集, 436, 59-69, 1992.6

6)村山袥司: 東京大都市圈における土地利用の転換過程一マルコフ連鎖モデ ルを利用して一,「日本の三大都市圈 その变容と将来像」高橋伸夫·谷 内達編，古今暳院，49-72, 1994.11

7 ) 吉川徽ほか:用途地域指定の主旨からみた土地利用遷移の分析, 日本都市 計画学会学術研究論文集 , 25, 373-378, 1990.10

8 ) 大佛俊泰・倍田賢一: 安定地点を考虑した土地利用遷移予測モデル，GIS理論と応用，vol.4, no. 2, pp.1-6, 1996.8

9 ) 大佛俊泰·栗崎直子: 効用概念に基づく土地利用遷移確率モデルの構筑と その応用，GIS- 理論と応用，vol.4，no. 2,pp.7-14，1996.8

10)吉川徽:多項分布による敷地土地利用転換モデルに関する考察, 総合都市 研究, 53,113-121，1994.9

11）大佛俊泰·倍田賢一・青木義次: 都市メッシュデータを用いた土地利用要 移確率行列の推定方法, 総合都市研究 65, pp. 25-34, 1998.3

12）坂元慶行·石黑真木夫 - 北川源四郎: 情報量統計学, 共立出版, 1983.1

13）大佛俊泰·清水貴雄 $\cdot$ 吉川 徽: 建築物の寿命に及はす要因分析, 地理情 報システム学会講演論文集 Vol.9,pp.141-146,2000.10

14）大佛俊泰·清水貴雄 $\cdot$ 吉川 徹: 建築物の除却要因と残存率の推定, 日本 建築学会大会学術講演梗概集(F-1) pp. 801-802, 2000.9

15）東京都三鹰市:三鷹市都市構造シミュレーション, 東京都三鶷市，2000

16）大佛俊泰·西松照生·吉川徽：画地単位の転換確率を用いた土地利用転 換分析，地理情報システム学会講演論文集 Vol.9, pp. 147-152, 2000.10 